\title{
HISTOCHEMICAL STUDIES OF RHEUMATIC CONDITIONS \\ I. OBSERVATIONS ON THE FINE STRUCTURES OF THE MATRIX OF NORMAL BONE AND CARTILAGE
}

BY

\author{
H. T. FAWNS and J. W. LANDELLS \\ From the Department of Biochemistry and the Bernhard Baron Institute of Pathology, \\ London Hospital Medical College, Whitechapel, London
}

(RECEIVED FOR PUBLICATION FEBRUARY 9, 1953)

Recently, specific enzymes have become available in highly purified form, which will attack the two main constituents of the ground substance of connective tissue.

Collagenase (from $\mathrm{Cl}$. Welchii filtrates, purified by the method of Bidwell and van Heyningen, 1948), attacks collagen but has a negligible action on other proteins.

Hyaluronidase (Benger) acts upon the mucopolysaccharide components, not only those built up from hyaluronic acid as the repeating unit, but also upon chondrin, where the repeating unit is chondroitin sulphuric acid.

Trypsin, on the other hand, will digest the majority of normal proteins, but will not attack collagen unless this has been denatured by some form of pre-treatment, e.g. by heat or by 20 per cent. urea solution.

The use of these enzymes for the differential removal of the ground substance components from histological sections, followed by specific staining methods for these components to see the extent to which they have been attacked by their enzymes, should provide a convenient method of investigating the chemical nature of rheumatic changes. But, before undertaking a study of rheumatoid material, it is necessary to apply the method to normal tissues: firstly, in order to obtain results which can be used as a set of controls, and secondly for purposes of standardizing the technique.

The present communication deals with the results obtained from normal bone and cartilage.

\section{Methods}

Material.- The articular cartilage of apparently normal human knee joints obtained at autopsy was used. Sections of the whole thickness of the cartilage and the underlying articular lamella were used, either cut frozen without fixation or decalcification, or fixed in 70 per cent. ethanol and decalcified before paraffin embedding in
1 per cent. hydrochloric acid in 70 per cent. ethanol. After this collagenase will still work, though at a reduced speed, whereas formalin fixation inhibits it more or less completely.

In these sections there is a zone of each kind of tissue, collagen with almost no chondrin in the superficial fifth of the cartilage, collagen and chondrin in the next threefifths, collagen, chondrin, and calcium in the basal fifth, and collagen and calcium phosphate in the strip of lamellar bone below this.

Staining.-The presence of the chondrin was followed by metachromatic staining with toluidine blue, $0.02 \mathrm{per}$ cent. at $p \mathrm{H} 3 \cdot 5$, and the less highly polymerized polysaccharide by staining with the periodic acid-Schiff method. The distribution of the two kinds of polysaccharide is quite distinct, though both are sometimes present together.

The relation between the chemical structure of the chondrin and its staining reactions is based on the original observations of Lison (1936) and Michaelis (1947) on metachromatic staining with toluidine blue and similar dyes, and on the use of periodic acid to oxidize adjacent glycol groups (Hotchkiss, 1948). Michaelis, on physicochemical grounds, relates metachromatic staining to polymerization of the dye molecules, but, with less evidence, relates this in turn to polymerization of the substrate. Lison merely regarded the metachromasia as evidence of the presence of sulphuric esters of high molecular weight. Now, it is known from analysis that the primary alcohol group on carbon-6 of the galactosamine is always sulphated in chondrin (Formula 1).

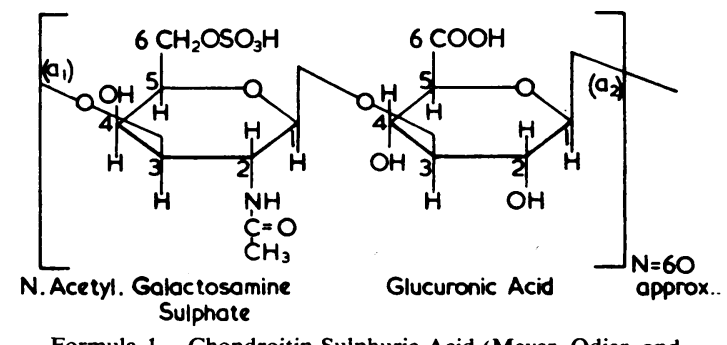

Formula 1.-Chondroitin-Sulphuric Acid (Meyer, Odier, and Sigrist, 1948). 
Changes in metachromasia must therefore be related to alteration in the freedom of this sulphate group.

The formula recently given by Meyer, Odier, and Siegrist (1948) for chondroitin-sulphuric acid (Formula 1) leaves only the ends of the molecular aggregates available for periodic acid-Schiff oxidation which requires the presence of two adjacent glycol (-CHOH-) groups. These investigators give the molecule as a straight chain polysaccharide, consisting of approximately 60 units of a repeating disaccharide composed of $\mathbf{N}$ acetyl.-galactosamine and glucuronic acid, joined throughout by a $1: 3$ linkage. As the requisite molecular structure can only occur at the end of these molecules, they should stain but weakly with the P.A.S. method. Breakdown in molecular size increases the number of such end-groups, so that an increase in the intensity of the P.A.S. staining reaction should result. Formula 2, depicting the repeating disaccharide, shows how such groups arise by hydrolysis -of the links attaching it to the adjacent units $\left(A_{1}\right.$ and $A_{2}$ are the reacting groups). The actual mechanism of the P.A.S. reaction consists in the oxidation by periodic acid of two adjacent glycol groups to give two aldehyde groups (Formula 3), which then react with Schiff's reagent to give a red colour. An alternative formula, put forward earlier by Bray, Gregory, and Stacey (1944) and by Haworth (1947), gives the repeating unit as a branching trisaccharide containing an additional molecule of glucuronic acid joined to the first by a $1: 2$ linkage (Formula 4). Here, too, the same principle would hold.

Direct observations of the toluidine blue and P.A.S. methods of staining show that their results are commonly reciprocal. The hyaline cartilage of the foetus is intensely metachromatic with toluidine blue, but quite negative to P.A.S., and the areas of adult cartilage staining most metachromatically with the former, also show the weakest reaction with P.A.S.* The specificity of staining with P.A.S. is, however, so wide that positive reactions require more careful interpretations than negative ones. It merely implies the presence of a double glycol grouping without giving information as to the rest of the molecule, and it is conceivable that these might arise in the material under treatment otherwise than by the polysaccharide breakdown shown in the above formulae.

Pre-treatment with "Hyalase"' would break the polysaccharide chains completely to their constituent units, which are sufficiently small and soluble to diffuse away, so that subsequent P.A.S. staining would give a negative result. This is borne out by experience.

The presence of calcium was determined by alizarin or Von Kossa's technique, which always corresponded. Collagen was stained by Van Gieson's method.

Decalcified sections were obtained by the use of O.1.N. hydrochloric acid on the cut sections for 5 minutes at room temperature. In these the calcium was completely removed but it is unlikely that any significant hydrolysis of the protein or polysaccharide would have occurred. Alternatively, prolonged exposure of tissues in bulk was carried out before embedding in paraffin using 1 per cent. $\mathrm{HCl}$ in 70 per cent. ethyl alcohol.

\footnotetext{
- There are local exceptions to this.
}

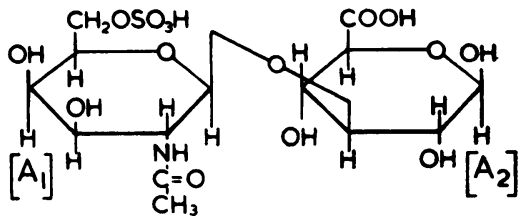

DISACCHARIDE UNIT. Hydrolysis of $1: 3$ links at $O_{1}$ and $O_{2}$ in Formula 1 has produced adjocent glyed groups at $A_{1}$ and $A_{2}$ in Formula 2. Oxidation of these with periodic acid converts them to aldehydes which give a red colour with Schiff's reogent.

Formula 2.-Chondroitin-Sulphuric Acid.

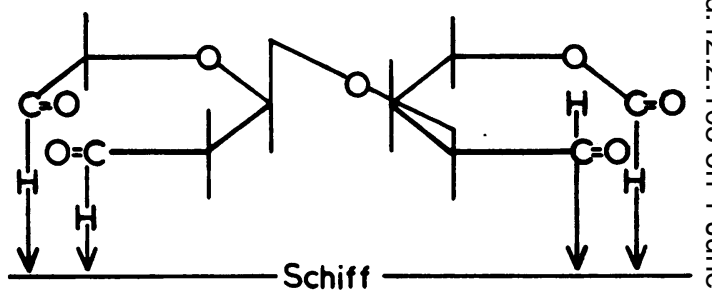

Formula 3.-Chondroitin-Sulphuric Acid.

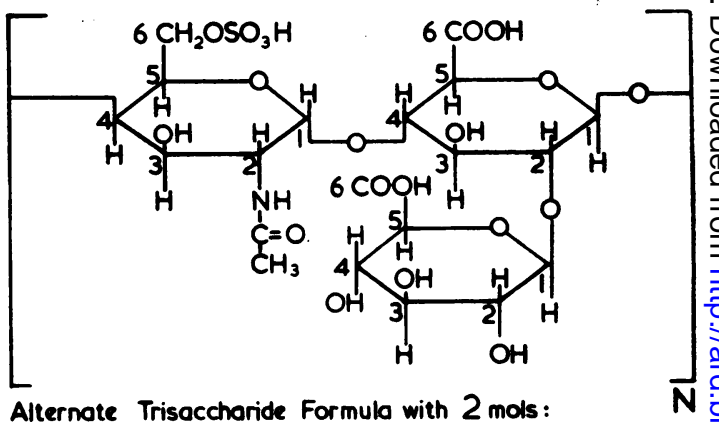

Givaronic Acid

Formula 4.-Chondroitin-Sulphuric Acid (Bray, Gregory, and Stacey (1944); Haworth, (1947)).

Enzyme Treatment.-The sections were incubated $>$ loose in pots of the enzyme solutions and subsequently transferred to normal saline prior to stain- N ing and mounting on slides. Where more than one ${ }^{\circ}$ enzyme treatment was applied, they were washed by $N$ floating in saline prior to transferring to the next $\underset{\mathrm{N}}{\mathrm{N}}$ enzyme solution.

The enzyme preparations employed were:

(i) Hyaluronidase.-Benger's "Hyalase" at a concen- $\overparen{\mathbb{D}}$ tration of 2,000 "Benger Units" in $25 \mathrm{ml}$. saline for $?$ 20 hours at $37^{\circ} \mathrm{C}$. which allows for slight variations of $\underline{T}$ potency in individual 1,000-unit batches of the material. The enzyme acts only on fresh material.

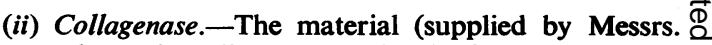
Burroughs and Wellcome) consisted of the K-toxin of 
TABLE

TRYPSIN AND COLLAGENASE SPECIFICITY TESTS

Two Substrates placed in two Sets of four Test Tubes each and treated with $10 \mathrm{ml}$. of four Solutions (incubation 2 hrs at $37^{\circ} \mathrm{C}$.).

\begin{tabular}{|c|c|c|c|c|c|c|c|}
\hline \multirow[b]{2}{*}{ Enzyme } & & \multirow[b]{2}{*}{ Substrate } & \multirow[b]{2}{*}{ Result } & \multicolumn{4}{|c|}{ Solution } \\
\hline & & & & $\begin{array}{c}\text { Phosphate } \\
\text { Buffer } \\
(p \mathrm{H} \mathrm{8)}\end{array}$ & $\begin{array}{l}0.5 \text { per cent. } \\
\text { Trypsin in } \\
\text { Phosphate Buffer }\end{array}$ & $\begin{array}{c}\text { Borate } \\
\text { Buffer } \\
(p H \mathbf{7} \cdot 4)\end{array}$ & $\begin{array}{l}\text { Collagenase } \\
\text { ( } 1 \mathrm{mg} . / \mathrm{ml} .) \text { in } \\
\text { Borate Buffer }\end{array}$ \\
\hline \multirow[t]{2}{*}{ Trypsin } & \multirow[t]{2}{*}{$\ldots$} & \multirow{2}{*}{$\begin{array}{l}100 \text { mg. dry } \\
\text { powdered fibrin }\end{array}$} & Macroscopic & No change & $\begin{array}{l}\text { Cloudy, approxi- } \\
\text { mately half dis- } \\
\text { solved }\end{array}$ & No change & No change \\
\hline & & & $\begin{array}{l}\text { Non-protein } \mathbf{N} \\
\text { (mg.) }\end{array}$ & $0 \cdot 14$ & $1 \cdot 33$ & $0 \cdot 14$ & $0 \cdot 14$ \\
\hline \multirow[t]{2}{*}{ Collagenase } & \multirow[t]{2}{*}{$\cdots$} & \multirow{2}{*}{$\begin{array}{l}10 \mathrm{ml} \text {. concen- } \\
\text { trated collagen } \\
\text { suspension }\end{array}$} & Macroscopic & $\begin{array}{l}\text { No change, } \\
\text { opaque }\end{array}$ & $\begin{array}{l}\text { No change, } \\
\text { opaque }\end{array}$ & $\begin{array}{l}\text { No change, } \\
\text { opaque }\end{array}$ & $\begin{array}{l}\text { Water-clear, only } \\
\text { few coarse strands } \\
\text { left }\end{array}$ \\
\hline & & & $\begin{array}{l}\text { Non-protein } \mathbf{N} \\
\text { (mg.) }\end{array}$ & 2.06 & 2.06 & $2 \cdot 06$ & $3 \cdot 70$ \\
\hline
\end{tabular}

Cl. Welchii, purified by the method of Bidwell and Van Heyningen (1948) and put up as a freeze-dried powder. Its strength was $13 \cdot 3 \mathrm{Q}$ units per $\mathrm{mg}$. (71 $\mathrm{Q}$ units per $\mathrm{mg}$. $\mathrm{N})$. Only traces of $\boldsymbol{\alpha}$-toxin, hyaluronidase, or desoxyribonuclease were stated to be present. It was readily soluble in Palitch's borax/borate buffer $p \mathrm{H} 7 \cdot 4$ in which it is stable. The concentration used was $1 \mathrm{mg}$. dry powder $/ \mathrm{ml}$. buffer. The incubation time was usually 24 hours at $37^{\circ} \mathrm{C}$.

(iii) Trypsin (L. Light and Co. Ltd.).-This was a purified preparation of trypsin in powder form, stated to be free from contamination by other enzymes. The strength used was 0.5 per cent. solution of powdered enzyme in phosphate buffer at $p \mathbf{H} 8$. Incubation was for one hour at $37^{\circ} \mathrm{C}$.

Tests for Enzyme Specificity.--It is necessary to show that collagenase will digest collagen but not other proteins, and conversely that trypsin will digest non-collagenous protein but not collagen. For the non-collagenous protein substrate, fibrin was chosen, as this protein was likely to be encountered later in pathological material. $100-\mathrm{mg}$. portions of dry, powdered fibrin were weighed out into four test tubes. To show collagenase activity, a collagen suspension, made from rat-tail tendons by the method of Nageotte and Guyon (1931), was used. By decanting off the supernatant fluid at intervals, the collagen was concentrated until a white, completely opaque suspension was obtained. The substrate consisted of $10 \mathrm{ml}$. of this collagen suspension. A second series of four tubes were put up.

10-ml. portions of the two enzyme solutions used for the histological work, and 10-ml. portions of their respective buffer solutions as controls, were added to the two sets of four tubes which were then incubated for $2 \mathrm{hrs}$ at $37^{\circ} \mathrm{C}$.

Enzyme activity was then assessed, both macroscopically and also by precipitating undigested protein with Somogyi's reagents and then estimating the non-protein-nitrogen (MicroKjeldahl) in the filtrates from these. The results are set out in the Table.

The results show the two enzymes to be satisfactory for the purpose in view. Trypsin will readily digest fibrin but will not attack collagen, whereas collagenase digests collagen but appears inactive against fibrin.

\section{Additional Tests}

(a) Trypsin.-Commercial preparations, which are usually made by glycerol extraction of pancreas, contain considerable amounts of both lipase and amylase. Heavy contamination with these might digest any lipoid or glycogen present in the sections and affect the histological picture. To test for lipase, the substrate used was $3 \mathrm{ml}$. alkaline litmus-milk, any change of colour from blue towards pink being observed, while $3 \mathrm{ml}$. 1 per cent. starch solution was used as substrate for amylase. Starch hydrolysis was tested for with Benedict's solution and also with iodine for residual starch.

Control tubes using boiled enzyme were put up and a commercial trypsin preparation was tested similarly for comparison. Incubation was for $1 \mathrm{hr}$ at $37^{\circ} \mathrm{C}$.

No amylase and only a slight trace of lipase could be detected in our preparation whereas the commercial preparation was strongly positive for both.

(b) Hyaluronidase.-Naked-eye observation of tests carried out with collagen suspension and fibrin sufficed to show the "Hyalase" preparation to be inactive against these substrates. Pilot trials carried out on sections and followed by toluidine blue or P.A.S. staining had shown it to be active against the mucopolysaccharides present, and capable of bringing about their complete removal.

\section{Results}

Normal Findings (Figs $1 a, 2 a, 4 a$, and $4 f$ ). -The normal superficial zone of cartilage with transversely laid fibres contains collagen and a small amount of low polymer polysaccharide; high polymer is present in small quantity on the surface of the flattened cells only. 

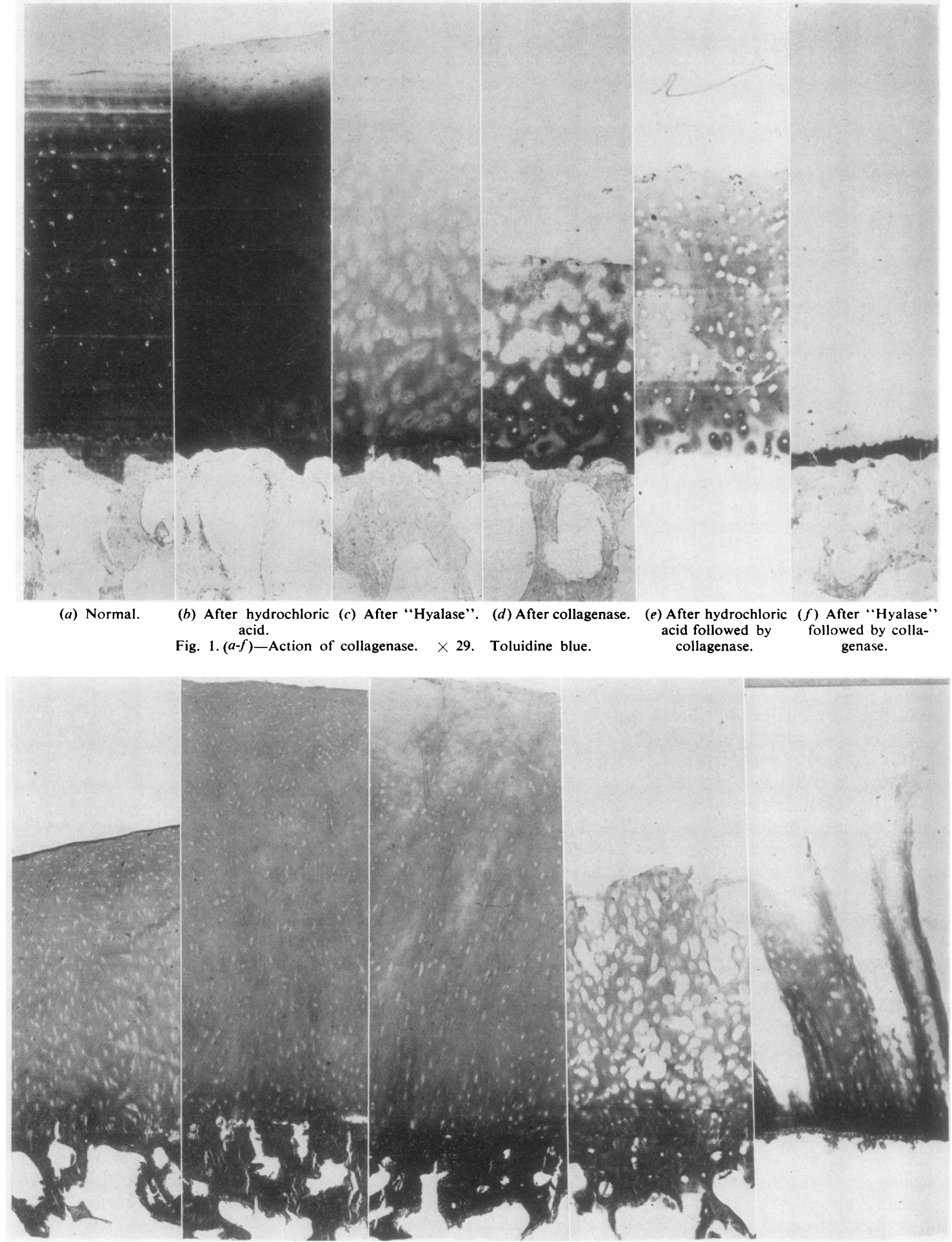

(a) Normal or after (b) After hydrochloric acid. (c) After collagenase. "Hyalase".

Fig. 2. (a.e)-Action of collagenase. $\times 18$. Van Gieson.

(d) After "Hyalase" followed by collagenase. 


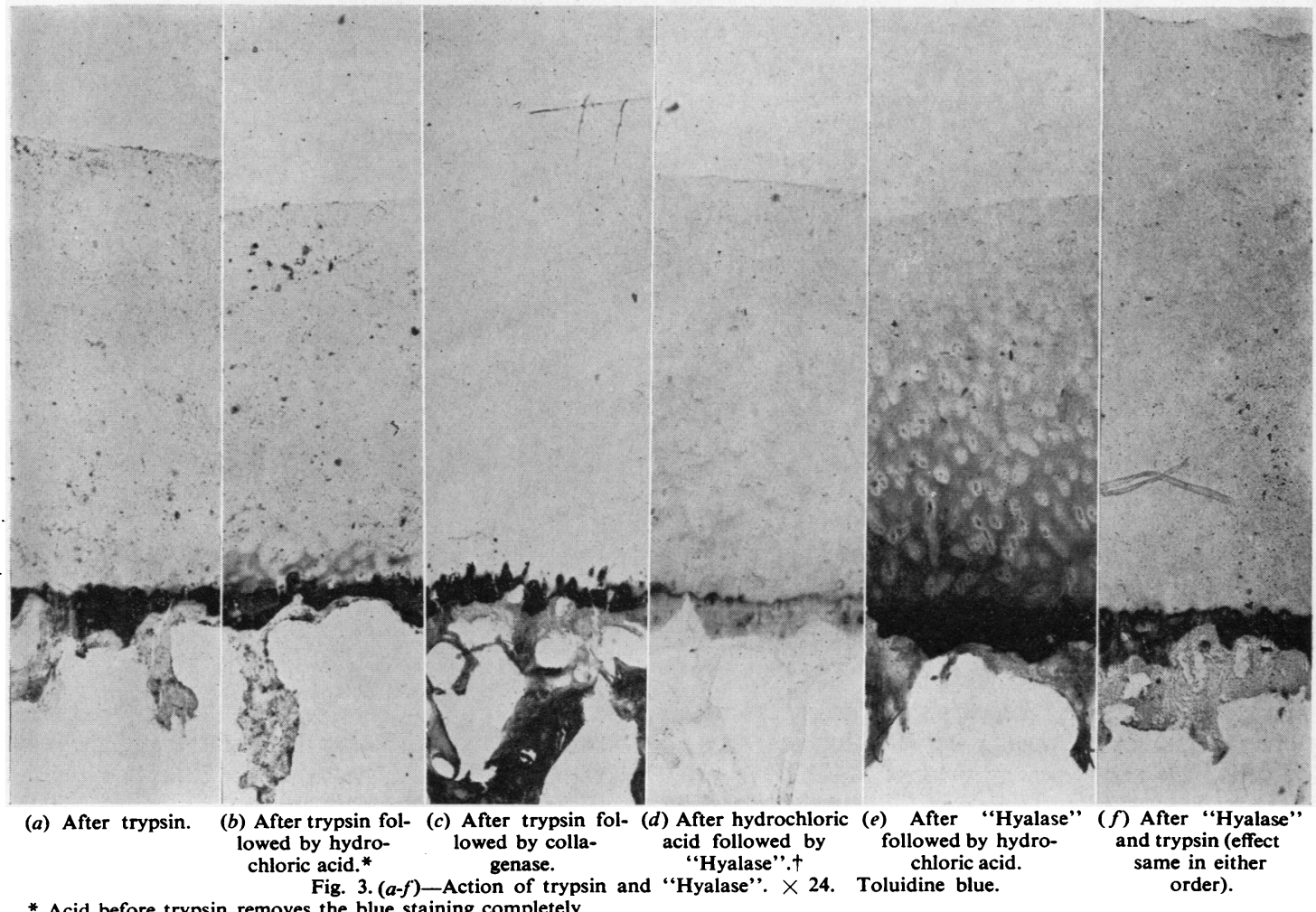

* Acid before trypsin removes the blue staining completely.

+ For'action of $\mathbf{H C l}+$ "Hyalase", see Fig. 1. Neither "Hyalase" nor trypsin affects Van Gieson staining.

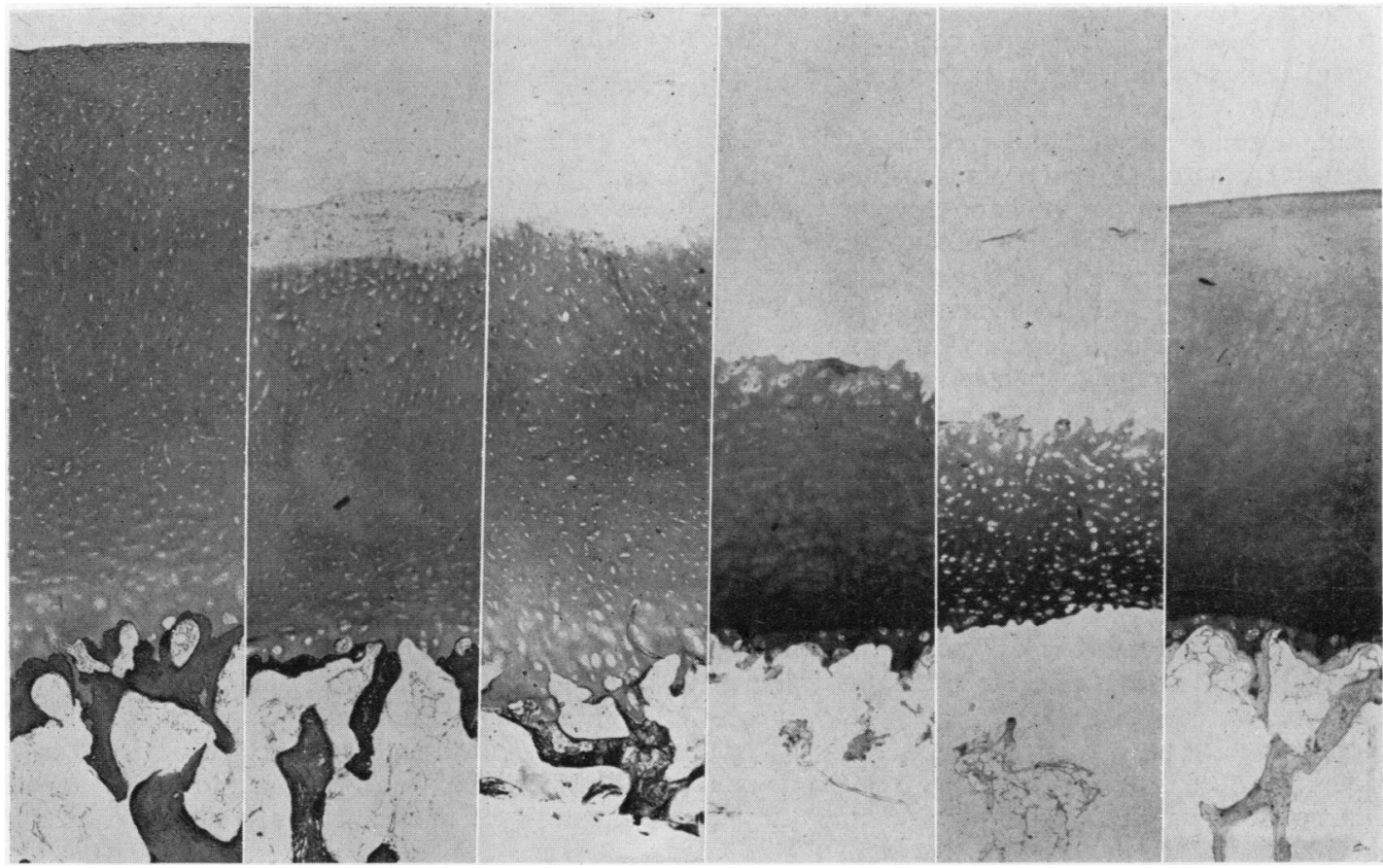

(a) Normal. (b) Collagenase 24 hrs. (c) Collagenase 36 hrs. (d) Collagenase 60 hrs. (e) Collagenase 112 hrs. ( $f$ ) Control-borate

Fig. 4. (a-f)-Detail of collagenase action. Paraffin sections after acid decalcification. $\times 23$. a-c) Van Gieson.

$(d-f)$ Periodic acid-Schiff, which distinguishes the calcified zone better. 


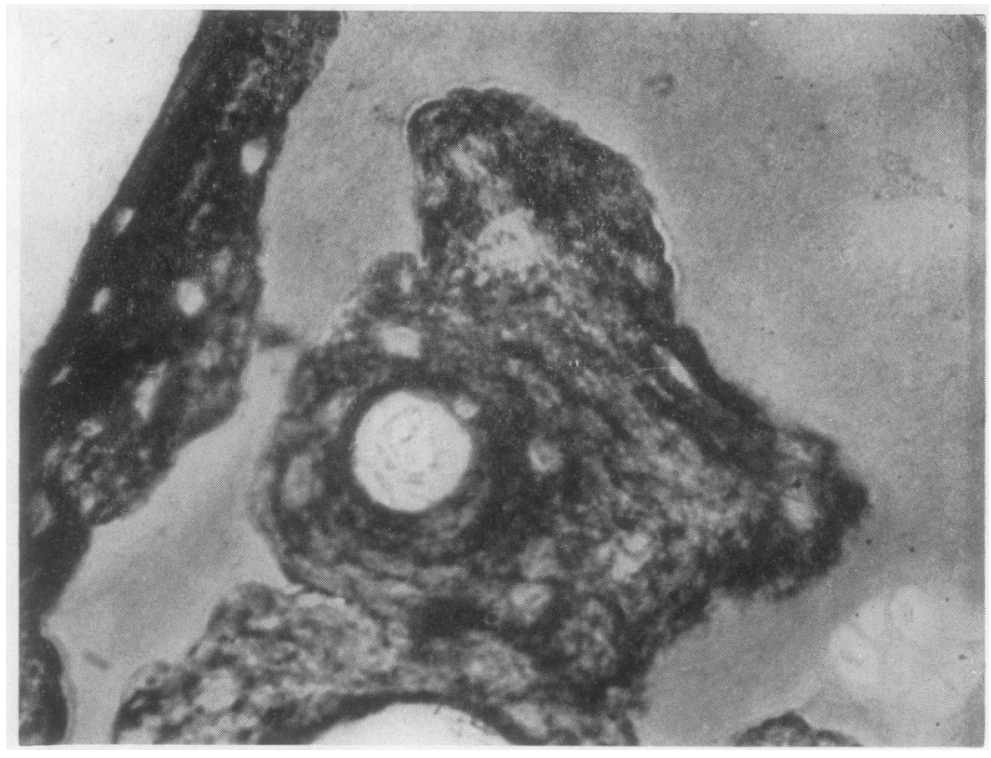

Fig. 5.-Detail of bone digestion. $\times 360$. Van Gieson.

In the next zone the high polymer becomes much more conspicuous, forming pools diffusing around the cells, but rather less is present in the bands of fibres well away from the cells. Collagen is present throughout in very delicate fibrils whose existence and distribution is better shown by the configuration of the cells and their surrounding chondrin haloes and the lines along which normal cartilage splits in fractures, than by histological techniques which may introduce artefacts. In some cartilage in older people, the chondrin in the fibre bands falls off rapidly towards the basal zone, and may be nearly absent, leaving the cartilage eosinophil in the ordinary haematoxylin and eosin stain; the included cells remain strongly basophil and metachromatic.

The plane marking the apex of the calcified zone is a line of transition differing greatly from the tissue on either side. In the haematoxylin and eosin section it appears as a highly characteristic landmark of wavy granular purple, advancing more rapidly between the cells and held back opposite them and their pools of chondrin. The form of the line suggests the name "tidemark" which is brief and convenient: it marks the limit of calcification but is not actual calcium, since it is conspicuous in decalcified sections. The form of the line (Fig. 6) is suggestive of the front of a stream of calcium diffusing up from the bone, and is difficult to account for otherwise; further evidence for this is its frequent reduplication, recalling the Liesegang ring phenomenon which results from such diffusion into a gel: if this is correct, the name is fitting. The line is one of structural as well as topographical importance, since it marks the position of the plane of greatest weakness, clefts parallel to the joint surface occurring preferentially in this zone (Fig. 7) and far more readily than at the more obvious junction between cartilage and bone. The tidemark is not, however, a piece of cartilage which is embryologically, or otherwise structurally, different from the rest, but a plane that moves slowly away from the bone after the finish of growth and ossification in the adolescent articular lamella. Until then, the calcified cartilage is replaced by bone as soon as it is formed, but, with the formation of a stable bony plate at the base of the cartilage, a calcified band develops adjacent thereto. This is not strictly "provisional calcification" since it does not ordinarily ossify and, indeed, marks the end of progressive ossification. The "tidemark" represents the most recently calcified border of this calcified zone, a transition stage with on one side, cartilage that has passed through it, and on the other, ordinary hyaline cartilage that will shortly become calcified. In the middle it is free from staining for either high or low polymer polysaccharide, but on the borders are heavy granular deposits staining for calcium and both types of polysaccharide; even after removal of the calcium, the matrix retains the heavy basophilia that is so conspicuous in haematoxylin and eosin sections. The central part takes the picric acid component of Van Gieson's stain after decalcification.

The calcified zone stains with both P.A.S. and toluidine blue, though less metachromatically than in the uncalcified zone. The staining is uniform in contrast to the unevenness of the uncalcified zone, 
Fig. 6._"Tidemark." $\times 77$. Toluidine blue.

Bone almost unstained, calcified cartilage pale grey, uncalcified cartilage dark grey. Original line of bone across bottom left corner, with "tidemark" reduplicated. New diffusion of calcium from osteophyte across bottom right corner nearly at right angles. "Tidemark" advancing between cells and their chondrin haloes, but held up opposite to them. Intense sharply limited haloes round cells in calcified zone.
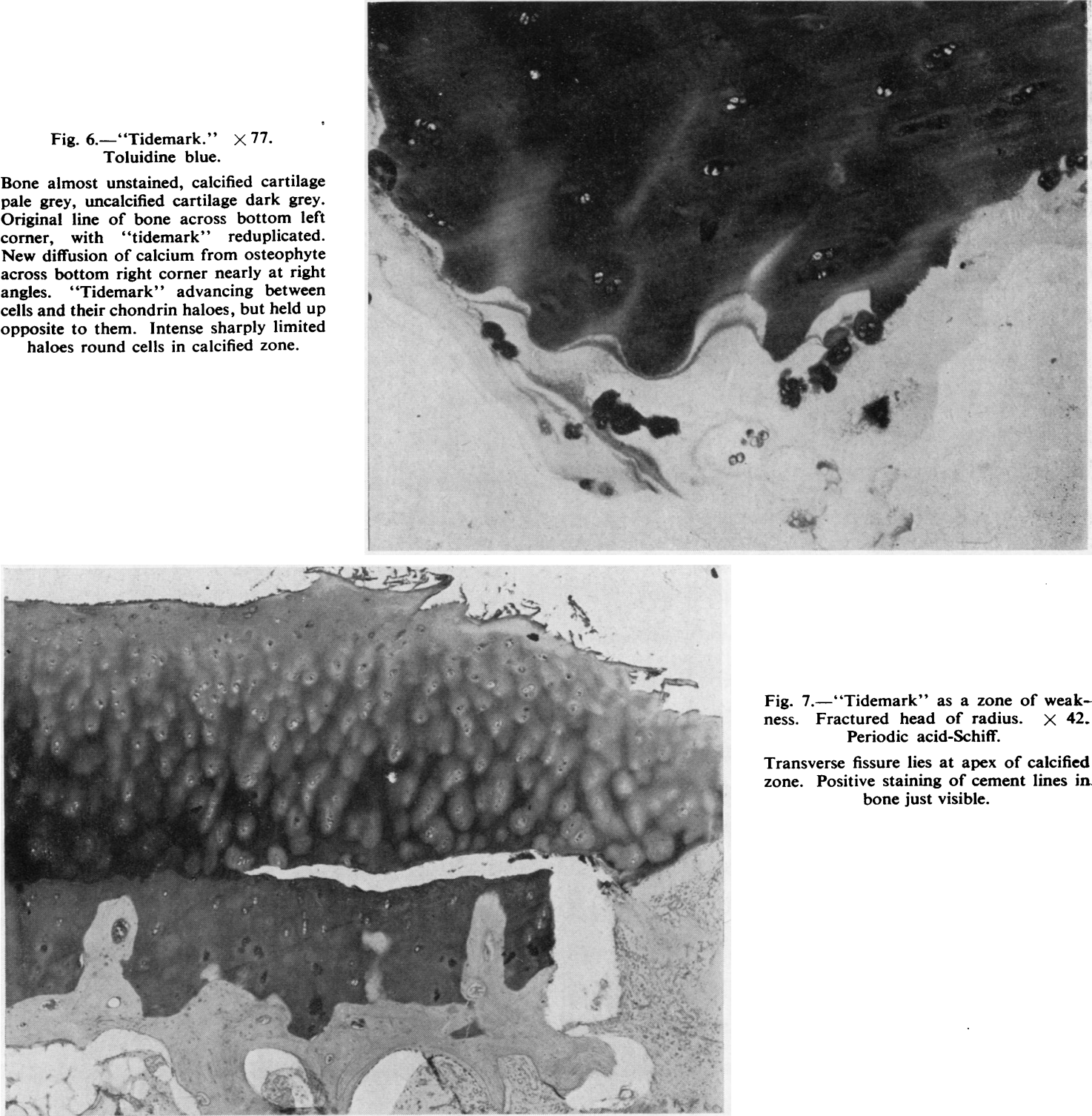

Fig. 7.- "Tidemark" as a zone of weakness. Fractured head of radius. $\times 42$. Periodic acid-Schiff.

Transverse fissure lies at apex of calcified zone. Positive staining of cement lines in bone just visible.

and around the surviving cells unusually deep haloes of polysaccharide are found with sharply defined borders (Fig. 6). This suggests that the diffusion of the chondrin is impeded compared with that in the uncalcified zone, because the molecules formed are larger, or the charges carried are different, or the calcified matrix is less permeable-another example of this change occurs when alginates are crosslinked by calcium. Calcium is present uniformly throughout the matrix. On the borders of the bone are found a double layer of a stain-free line and a granular layer of polysaccharide, somewhat resembling the tidemark, but without its weakness and never reduplicated.

In the bone, the lamellae contain collagen and calcium, but no polysaccharide can be demonstrated in them. The cement lines between systems, however, are low polymer polysaccharide without calcium or collagen. Woven bone fibres contain granular deposits staining for both calcium and polysaccharides (both by P.A.S. and by toluidine blue); osteoid is collagen only. 


\section{Action of Reagents}

(i) Hydrochloric Acid (Figs $1 b, 2 b$, and $4 a-f$ ).-As well as removing the calcium, the metachromasia of the calcified chondrin reverts to the intense metachromasia normal to the uncalcified part. This occurs regularly when the calcium is removed, but may also occur without decalcification, through the action of heat, storage in saline, and several other treatments.

(ii) Hyaluronidase (Figs $1 c$, and $3 d-f$ ).-The chondrin is completely leached out of the uncalcified cartilage, that in the cells and their haloes before that in the fibre belts. The calcified zone retains both its calcium and its chondrin, though the latter shows heat reversion of its metachromasia. After decalcification, however (Fig. 3d), the chondrin is broken down, that in the tidemark zone after that in the older calcified cartilage. The collagen is unchanged throughout.

(iii) Collagenase (Figs $1 d-f, 2 c-e, 3 c$, and $4 a-f$ ). - In all cases the superficial fibres containing neither calcium nor chondrin are digested. The bone and the calcified zone are quite untouched in the fresh material, the intervening zone being variably digested starting with the cell spaces and the tissue immediately around them.

After decalcification, the bone is dissolved both in fresh and in paraffin sections, the rather better preparation of the paraffin material and the slower action of the enzyme making it easier to see the detailed advance of the process. The calcified cartilage is dissolved in the fresh material completely and rapidly, but in the paraffin is less rapidly attacked than bone (Figs. $4 d$ and 5).

After the use of "Hyalase" in the fresh material(Fig. 1f), the digestion of the uncalcified cartilage is much more rapid and complete. The effect begins in the cell spaces, and the cells and their haloes disappear while the denser fibre bands are untouched.

(iv) Trypsin (Fig. $3 a, b, c$, and $f$ ).-The collagen fibres are untouched and there is no decalcification. The chondrin is completely dissolved out of the uncalcified zone, that in the cells and their haloes before that in the fibre belts. In the calcified zone the chondrin becomes very densely stained to a bluish rather than a reddish purple, and this staining diffuses somewhat around the cartilage. After decalcification, the calcified zone chondrin is also removed by trypsin, but the dark purple material produced by trypsin in the fresh tissue is not removed by subsequent treatment with acid. After "Hyalase" the standard reaction is unchanged.

The uncalcified zone is rendered abnormally sensitive to collagenase by removal of the chondrin, just as it is by pre-treatment with "Hyalase", but the change in the calcified zone does not alter its resistance to collagenase.

\section{Discussion}

(1) Relation between Collagen and Calcium.-The presence of the calcium near the collagen appears to be a complete bar to the action of the collagenase. As we do not know the point of action of this enzyme, we can only assume that it is in some way covered by the calcium, possibly by the cross-linking of adjacent? fibrillae or by the bending of the fibres: the presence $\vec{F}$ of calcium ions does not affect the action of colla-? genase, and the effect is so easily reversible by응 dissolving the calcium that no great rearrangement $\frac{}{\bar{c}}$ of the protein appears to be possible.

(2) Relation between Collagen and Chondrin.-The position is less clear where chondrin is concerned. The collagenase effect is delayed when there is much? chondrin, and is expedited when the chondrin is $\vec{\omega}$ dissolved away, but the bar to action is not as absolute as in calcified tissue, possibly because the $\frac{\stackrel{\omega}{2}}{2}$ chondrin dissolves away from exposed surfaces more readily than the calcium. The relation may be $N$ one of mere proximity, the collagen fibres running $\vec{P}$ through the polysaccharide in such a way that the enzyme cannot reach them, but the action of trypsin 응 suggests possibilities of a direct link between the acid group of the polysaceharide and the amino $c$ groups of the protein (Haworth, 1947).

Support for this comes from the observation that $\vec{A}$ the intensity of toluidine staining - which is related of to the acid groups of the polysaccharide and to the $\omega$ amino groups of the stain-is greatest near the cells from which the chondrin is produced and from which it diffuses, and becomes less when far away from them, where it might well have formed such linkages with protein and be unable to pick up the stain. $\stackrel{\square}{\complement}$ Thus the action of trypsin in removing chondrin $\overrightarrow{\vec{O}}$ would be explained as the breaking of such a link.

(3) Relation between Chondrin and Calcium.-In the calcified zone, diffusion is impaired-as can be judged from the intensity and form of the haloes of the surviving cells in this zone, and from their frequent death in spite of their low oxygen require- 3 . ments. Further, the degree of metachromasia is $\delta$ altered and reverts to that of normal cartilage when $₹$ the calcium is removed, and we believe the meta- 0 chromasia to be related to acidic groups and especially to sulphate groups in the chondrin. Again, the action of "Hyalase"' is here held up just like that of collagenase, and is liberated by decalcification. Now, $\odot$ this zone is not made separately from the uncalcified $N$ zone or of different components, but is formed from it whenever bone and cartilage remain unaltered in 0 contact with each other for a period of years; and the form of the line separating the calcified and uncalcified zones suggests that the change is due to diffusion of calcium. The interference with the two 0 enzymes so caused can hardly be explained except $\overline{0}$ by combination of the calcium with their substrates, $\stackrel{\mathbb{D}}{\stackrel{8}{\circ}}$ since ionic and $p \mathrm{H}$ changes within reasonable limits $\mathbb{\mathbb { D }}$ do not upset the enzymes; and such combination will 
also cover the changes in diffusion and metachromasia, and is known to occur in chemically similar alginates.

The action of trypsin on this zone includes the exposure of a large number of acidic groups from the chondrin without decalcification, as is shown by the intense toluidine blue staining. This suggests that some of the chondrin acid groups are concerned with linkage to protein, and some with calcium fixation. There are plenty of such groups available.

This chemical difference between the enzyme reactions of calcified and uncalcified cartilage is paralleled by the different methods adopted by the body for their removal. The uncalcified part of the articular cartilage is easily digested by polymorphonuclear leucocytes in purulent inflammation, whereas dead cartilage in aseptic situations is removed directly and inconspicuously by fibroblasts after the chondrin present has diffused away, being no longer re-formed by the dead cells. In calcified cartilage, however, as in bone, the method of removal is always by giant-cell ("osteoclastic") resorption, the calcium and the matrix being removed together; there is no previous removal, either by diffusion or by cellular action, of the chondrin in the cartilage.

\section{Summary}

(1) The action of collagenase on the fibres of lamellar bone is completely inhibited until the calcium is removed by acid; the strength and duration of the acid treatment is unlikely to have any hydrolytic effect on the collagen.

(2) The action of collagenase on the fibres of hyaline articular cartilage is delayed, though not inhibited, proportionally to the content of polysaccharide in the cartilage, and if this polysaccharide is removed the effect is complete and rapid.

(3) In the calcified zone of articular cartilage, where both chondrin and calcium are present, neither collagenase nor "Hyalase" has any action until the calcium is removed.

(4) The difference in enzyme reactions between calcified and uncalcified tissues is apparent in vivo in the methods used by the body for their breakdown.

(5) The evidence supports the view that the calcium and the collagen in particular, the chondrin and the calcium almost as certainly, and the chondrin and the collagen less clearly, are chemically linked rather than merely close neighbours.

We should like to thank Mr. Victor Trenwith for technical assistance, Mr. A. J. King for the photo- micrographs, and the Yarrow Research Fund of the London Hospital for a grant towards expenses.

\section{REFERENCES}

Bidwell, E., and van Heyningen, W. E. (1948). Biochem. J., 42, 140. Bray, H. G., Gregory, J. E., and Stacey, M. (1944). Ibid., 38, 142. Haworth, W. N. (1947). J., chem. Soc., p. 582 .

Hotchkiss, R. D. (1948). Arch. Biochem., 16, 131.

Lison, L. (1936). "Histochimie Animale," p. 236. Gauthier-Villars, Paris.

Meyer, K. H., Odier, M. E., and Siegrist, A. E. (1948). Helv. chim. Acta, 31, 1400 .

Michaelis, L. (1947). Cold Spr. Harb. Symp. quant. Biol., 12, 131. Nageotte, J., and Guyon, L. (1931). Arch. Biol., Paris, 41, 1.

Etudes biochimiques des affections rhumatismales 1. Observations sur les structures

trabéculaires de l'os et du cartilage normaux RÉSUMÉ

(1) L'action de la collagénase sur les fibres de l'os lamellaire est totalement inhibée jusqu'à ce qu'on ait extrait le calcium par un acide; il est peu probable que la force et la durée du traitement acide ait un effet hydrolytique sur le collagène.

(2) L'action de la collagénase sur les fibres du cartilage articular hyalin sans être inhibée est retardée proportionnellement à la teneur du cartilage en polysaccharide; quand on extrait le polysaccharide, l'action devient complète et rapide.

(3) Dans la zone calcifiée du cartilage articulaire, en présence tant de la chondrine què du calcium, aussi bien la collagénase que la "hyalase" n'agissent qu'après qu'on ait extrait le calcium.

(4) La différence entre les réactions enzymatiques dans les tissus calcifiés et non-calcifiés est apparente in vivo dans les méthodes employées par l'organisme pour les décomposer.

(5) Il y a des preuves montrant l'existence d'un lien chimique, plutôt que d'un rapport de voisinage, en particulier entre le calcium et le collagène, presque certainement entre la chondrine et le calcium et peut-être aussi entre la chondrine et le collagène.

Estudios bioquímicos de las afecciones reumáticas

1. Observaciones sobre las estructuras trabeculares del hueso y del cartílago normales

\section{Sumario}

(1) La acción de la colagenasa sobre las fibras del hueso lamelar queda completamente inhibida mientras no se extraiga el calcio con un ácido; la fuerza y la duración del tratamiento ácido no parece tener efecto hidrolítico sobre el colageno.

(2) La acción de la colagenasa sobre las fibras del cartílago articular hialino se ve retardada pero no inhibida proporcionalmente a su contenido de polisacarido; al extraer el polisacarido, el efecto es completo y rápido.

(3) En la zona calcificada del cartílago articular, en la presencia de la condrina y del calcio, tanto la colagenasa como la "hialasa" no actuan mientras no se extraiga el calcio.

(4) $\mathrm{La}$ diferencia entre las reacciones enzimáticas en los tejidos calcificados y sin calcificar es aparente in vivo en los métodos empleados por el organismo para su destrucción.

(5) Hay pruebas mostrando la existencia de un vínculo químico más bien que de vecindad, entre el calcio y el colageno en particular, entre la condrina y el calcio casi seguramente y, quizas, entre la condrina y el colageno. 